\title{
Sosialisasi Perpajakan dan Pengetahuan Pajak Terhadap Kepatuhan Pajak
}

\author{
Riri Zelmiyanti1 ${ }^{1}$, Diah Amalia ${ }^{2}$ \\ 1,2 Politeknik Negeri Batam, Kepulauan Riau, Kota Batam, Indonesia
}

\section{INFO ARTIKEL \\ JEL Classification :}

$\mathrm{H} 21, \mathrm{H} 25$

\section{Keywords :}

tax knowledge, tax

socialization, tax

compliance

\begin{abstract}
This study aims to examine tax information dissemination and tax knowledge on tax compliance. The method used in this study is a survey of taxpayers in Batam State Polytechnic. The analytical tool used is Structural Equation Modeling - Partial Least Square (SEM-PLS) using WarpPLS 6.0 software. H2 in this study is supported, tax socialization directly influences the significance of tax compliance $P<0.01$ with $R 2$ value of $28 \%$. Tax knowledge has an effect on tax compliance with a significance value of $P<0.01$ with $R 2$ value of 0.27 so that it supports H2. Knowledge of taxation partially mediates the effect of taxation socialization on tax compliance, the form of partial mediation shows that knowledge is not the only mediator of the relationship of socialization to tax compliance but there are other mediators.
\end{abstract}

\begin{abstract}
ABSTRAK
Penelitian ini bertujuan untuk menguji sosialisasi perpajakan dan pengetahuan pajak terhadap kepatuhan pajak. Metode yang digunakan pada penelitian ini yaitu survei terhadap wajib pajak di lingkungan Politeknik Negeri Batam. Alat analisis yang digunakan Structural Equation Modelling - Partial Least Square (SEM-PLS) menggunakan software WarpPLS 6.0. $\mathrm{H}_{2}$ pada penelitian ini terdukung, sosialisasi perpajakan berpengaruh secara langsung terhadap kepatuhan pajak signifikansi $\mathrm{P}<0,01$ dengan nilai $\mathrm{R}^{2}$ sebesar $28 \%$. Pengetahuan pajak berpengaruh terhadap kepatuhan pajak nilai signifikansi $P<0,01$ dengan nilai $R^{2} \quad 0,27$ sehingga mendukung $H_{2}$. Pengetahuan perpajakan memediasi secara parsiel pengaruh sosialisasi perpajakan terhadap kepatuhan pajak, bentuk parsiel mediasi menunjukan bahwa pengetahuan bukan satu-satunya pemediasi hubungan sosialisasi terhadap kepatuhan pajak namun terdapat pemediasi lain.
\end{abstract}

\section{Pendahuluan}

Indonesia merupakan negara yang mengandalkan pendapatan pada sektor pajak. Menurut data kementrian keuangan dalam postur Anggaran Pendapatan Belanja Negara 2018 pendapatan negara diproyeksi sebesar $\mathrm{Rp} 1.894,7$ triliun. Jumlah tersebut berasal dari sektor pajak $\mathrm{Rp} 1.618,1$ triliun sisanya berasal dari peneriman negara bukan pajak sebesar Rp275, 4 triliun dan hibah sebesar Rp 1,2 triliun. Jumlah tersebut menunjukan

*Email Korespondensi: ${ }^{2}$ diahamalia@polibatam.ac.id bahwa lebih dari $80 \%$ pendapatan negara berasal dari sektor pajak. Oleh karena itu dibutuhkan usaha untuk terus menggali sektor pajak.

Realisasi pendapatan pajak dalam negeri untuk Kepulauan Riau tahun 2018 Rp1.284,21 milyar mengalami penurunan dibanding periode yang sama pada tahun 2017 Rp1.500,21 milyar (Perbendaharaan, 2018), kurang maksimalnya pendapatan dari sektor pajak harus tetap digali. Banyak usaha yang dilakukan untuk meningkatkan kepatuhan 
pajak. Penelitian yang berhubungan dengan kepatuhan pajak sudah dilakukan di beberapa negara termasuk Indonesia. Penelitian kepatuhan pajak melihat dari perspektif baik ekonomi maupun perilaku. Berbagai bentuk sosialisasi perpajakan dapat dilakukan seperti melalui penyuluhan, seruan moral baik dengan media billboard, baliho, maupun membuka situs peraturan pajak yang setiap saat bisa diakses oleh Wajib Pajak.

Kesadaran akan kepatuhan pajak juga bisa ditingkatkan melalui pengetahuan pajak. Pengetahuan pajak adalah informasi pajak yang dapat digunakan wajib pajak sebagai dasar untuk bertindak, mengambil keputusan, dan untuk menempuh arah atau strategi tertentu sehubungan dengan pelaksanaan hak dan kewajibannya dibidang perpajakan (Faturahman, 2018).

Beberapa hasil penelitian membuktikan bahwa pemanfaatan teknologi informasi, sosialisasi perpajakan dan pengetahuan pajak berpengaruh signifikan positif terhadap kepatuhan pajak (Sudrajat, 2015). Di perkuat oleh penelitian yang dilakukan (Anwar, 2016) membuktikan sosialisasi perpajakan dan pengetahuan pajak berpengaruh positif terhadap kepatuhan pajak.

Berbeda dari hasil penelitian Pratomo menunjukkan sosialisasi perpajakan dan help desk secara bersama - sama tidak berpengaruh terhadap Kepatuhan Wajib Pajak. Pengujian secara parsial melalui Uji t menyatakan bahwa sosialisasi perpajakan tidak berpengaruh terhadap kepatuhan Wajib Pajak dan help desk tidak berpengaruh terhadap kepatuhan Wajib Pajak. Maka sosialisasi perpajakan dan pelayanan khususnya help desk perlu dievaluasi kembali (Pratomo, 2018).

Politeknik Negeri Batam sebagai lembaga akademisi yang sering bekerja sama dengan Direktorat Jendral Pajak dalam sosialisasi perpajakan akan memiliki pengetahuan lebih mengenai perpajakan. Namun menurut beberapa penelitian wajib pajak orang pribadi yang sebagian besar telah memiliki pendidikan cukup tinggi tidak menjamin memiliki pengetahuan pajak yang tidak terlalu luas.

Sesuai uraian diatas peneliti akan menguji bagaimana sosialisasi perpajakan, pengetahuan pajak terhadap kepatuhan pajak di Politeknik Negeri Batam dan menguji bagaimana sosialisasi perpajakan terhadap kepatuhan pajak melalui pengetahuan pajak di Politeknik Negeri Batam. Penelitian ini bertujuan untuk mengetahui secara empiris sosialisasi perpajakan dan pengetahuan pajak terhadap kepatuhan pajak di Politeknik Negeri Batam, sosialisasi perpajakan terhadap kepatuhan pajak melalui pengetahuan pajak di Politeknik Negeri Batam. Hasil penelitian ini dapat digunakan oleh direktorat jendral pajak dalam upaya meningkatkan pendapatan negara yang bersumber dari sektor pajak.

\section{Telaah Teori dan Pengembangan Hipotesis}

Penelitian yang membahas tentang kepatuhan perpajakan dapat menggunakan beberapa indikator salah satunya indikator perilaku wajib pajak orang pribadi berdasarkan Theory of Planned Behavior (TPB) atau perilaku yang direncanakan. Menurut Fishbein \& Ajzen Theory of Planned Behavior (TPB) bahwa perilaku yang dihasilkan oleh individu timbul karena adanya niat untuk berperilaku. Kemunculan niat untuk berperilaku ditentukan oleh tiga faktor yaitu: Keyakinan Perilaku (behavioral beliefs), Keyakinan Normatif (normative beliefs), Keyakinan Kontrol (control beliefs) (Andreas \& Savitri, 2015).

Menurut UU Nomor 28 Tahun 2007 tentang ketentuan umum dan tata cara perpajakan, Pajak adalah kontribusi wajib kepada negara yang terutang oleh orang pribadi atau badan yang bersifat memaksa berdasarkan undang-undang, dengan tidak mendapatkan imbalan secara langsung dan digunakan untuk kepeprluan negara bagi sebesar-besarnya kemakmuran rakyat (Resmi, 2017). Sosialisasi merupakan "Proses bimbingan individu kedalam dunia sosial. Sosialisasi dilakukan dengan mendidik individu tentang kebudayaan yang harus dimiliki dan diikutinya, agar ia menjadi anggota yang baik dalam masyarakata dan alam berbagai kelompok khusus, sosialisasi dapat dianggap sama dengan pendidikan (Sudrajat, 2015).

Menurut Harris pengetahuan pajak terbagi menjadi dua aspek, yaitu pengetahuan melalui pendidikan umum atau formal diterima sebagai hal yang biasa dan 
pengetahuan khusus diarahkan pada peluang yang mungkin untuk menghindari pajak. Menurut Eriksen \& Fallan bahwa pengetahuan tentang hukum pajak dianggap penting untuk preferensi dan sikap menuju perpajakan (Andreas \& Savitri, 2015). Kepatuhan Pajak adalah pelaporan penghasilan dan pembayaran pajak sesuai dengan undang-undang yang berlaku. Dengan demikian, pembayar pajak yang patuh akan melaporkan penghasilan dengan benar, dan membayar seluruh utang pajak dalam waktu yang tepat tanpa intervensi otoritas perpajakan (Alm, 1991).

Penelitian Sudrajat menunjukan bahwa pemanfaatan tekhnologi informasi, sosialisasi pajak dan pengetahuan pajak berpengaruh positif dan signifkan terhadap kepatuhan Wajib Pajak secara parsial. Untuk pengujian secara simultan berpengaruh terhadap kepatuhan pajak (Sudrajat, 2015). Diperkuat oleh hasil penelitian Anwar membuktikan bahwa sosialisasi perpajakan berpengaruh signifikan positif terhadap pengetahuan perpajakan dan kepatuhan perpajakan. Disamping itu, pengetahuan perpajakan juga mempengaruhi secara signifikan positif terhadap kepatuhan perpajakan sekaligus memediasi pengaruh sosialisasi perpajakan terhadap kepatuhan perpajakan Wajib Pajak UMKM di Surakarta (Anwar, 2016).

Sosialisasi perpajakan secara dampak, telah mampu memberikan peningkatan bagi kepatuhan atas pajak sesuai dengan Peraturan Pemerintah Nomor 46 Tahun 2013 dan indikator-indikator Wajib Pajak Patuh lainnya, meskipun dampak yang ada dapat terhalangi oleh alasan atau motif-motif tertentu yang mungkin saja terjadi. Sedangkan untuk tax amnesty sendiri, sosialisasi perpajakan yang ada telah mampu memberikan dampak bagi kepatuhan atas tax amnesty (Herlambang, 2018).

\section{Pengembangan Hipotesis}

\section{Pengaruh Sosialisasi Perpajakan terhadap Kepatuhan Pajak}

Penelitian Anwar membuktikan bahwa sosialisasi perpajakan berpengaruh signifikan positif terhadap pengetahuan perpajakan dan kepatuhan perpajakan. Peningkatan sosialisasi yang dilakukan oleh aparat pajak akan meningkatkan kepatuhan pajak (Anwar, 2016).
Semakin banyaknya sosialisasi perpajakan maka orang yang mengetahui manfaat pajak akan lebih banyak, sehingga kepatuhan juga akan meningkat. Oleh karena itu dapat dihipotesiskan:

$\mathrm{H}_{1}$ : Sosialisasi perpajakan berpengaruh signifikan positif terhadap kepatuhan pajak.

\section{Pengaruh Pengetahuan Pajak terhadap Kepatuhan Pajak}

Penelitian yang dilakukan oleh Anwar dkk membuktikan bahwa sosialisasi perpajakan berpengaruh signifikan positif terhadap pengetahuan perpajakan dan kepatuhan perpajakan (Anwar, 2016). Penelitian sudrajat menunjukan pemanfaatan tekhnologi informasi, sosialisasi pajak dan pengetahuan pajak berpengaruh positif dan signifkan terhadap kepatuhan (Sudrajat, 2015). Berdasarkan hasil penelitian tersebut dapat dihipotesiskan:

$\mathrm{H}_{2}$ : Pengetahuan Pajak Berpengaruh Signifikan Positif Terhadap Kepatuhan Pajak.

\section{Pengaruh Sosialisasi Perpajakan Terhadap Kepatuhan Pajak Melalui Pengetahuan Pajak}

Memberikan pemahaman terhadap wajib pajak mengenai fungsi pajak secara tidak langsung memberikan kesadaran kepada wajib pajak terhadap kepatuhan pajak. Semakin banyak sosialisasi yang dilakukan terhadap wajib pajak maka pengetahuan wajib pajak akan bertambah. Meningkatnya pengetahuan wajib pajak maka kesadaran untuk membayar pajak juga akan meningkat. Sejalan dengan penelitian Sudrajat menunjukan pemanfaatan tekhnologi informasi, sosialisasi pajak dan pengetahuan pajak berpengaruh positif dan signifkan terhadapkepatuhan Wajib Pajak (Sudrajat, 2015). Penelitian Anwar membuktikan bahwa pengetahuan pajak mampu memediasi hubungan sosialisasi perpajakan kepatuhan perpajakan (Anwar, 2016). Berdasarkan pemaparan di atas dapat dihipotesiskan:

$\mathrm{H}_{3}$ : Sosialisasi perpajakan berpengaruh signifikan positif terhadap kepatuhan pajak melalui pengetahuan pajak. 


\section{Metode Penelitian}

Penelitian ini menggunakan metode survai kuesioner. Alat analisis yang digunakan Structural Equation ModellingPartial Least Square (SEM-PLS) menggunakan software WarpPLS 3.0.P. Penelitian ini dilakukan di Politeknik Negeri Batam dengan obyek yang diteliti dan menjadi responden adalah seluruh Tenaga Pendidik dan Tenaga kependidikan.

Matriks yang menjelaskan variabel yang akan dikaji dan dianalisis, secara lengkap diuraikan dalam operasionalisasi variabel yang dapat dilihat pada Tabel 1 berikut:

Tabel 1 Matriks Operasionalisasi Variabel

\begin{tabular}{|c|c|}
\hline Variabel & Indikator \\
\hline $\begin{array}{l}\text { Sosialisasi } \\
\text { Perpajakan } \\
\left(\mathrm{X}_{1}\right)\end{array}$ & $\begin{array}{l}\text { 1. Penyuluhan } \\
\text { 2. Diskusi dengan wajib pajak } \\
\text { dan tokoh masyarakat } \\
\text { 3. Informasi langsung dari } \\
\text { petugas ke wajib pajak } \\
\text { 4. Pemasangan billboard } \\
\text { 5. Web site Ditjen Pajak }\end{array}$ \\
\hline $\begin{array}{l}\text { Pengatahuan } \\
\text { Perpajakan } \\
\left(\mathrm{X}_{2}\right)\end{array}$ & $\begin{array}{ll}\text { 1. } & \text { Fungsi dari Pajak } \\
\text { 2. Kewajiban membayar } \\
\text { pajak } \\
\text { 3. Perubahan peraturan } \\
\text { perpajakan } \\
\text { 4. Cara menghitung pajak } \\
\text { 5. Tarif pajak } \\
\text { 6. Sanksi }\end{array}$ \\
\hline $\begin{array}{c}\text { Kepatuhan } \\
\text { Wajib Pajak } \\
\text { (Y) }\end{array}$ & $\begin{array}{l}\text { 1. Kecenderungan pribadi } \\
\text { 2. Keputusan pribadi } \\
\text { 3. Penyerahan SPT } \\
\text { 4. Pembayaran } \\
\text { 5. Pelaporan } \\
\text { 6. Di periksa } \\
\text { 7. Sanksi }\end{array}$ \\
\hline
\end{tabular}

\section{Hasil Penelitan dan Pembahasan}

\section{Pengaruh Sosialisasi perpajakan terhadap Kepatuhan Pajak}

Sebelum melakukan pengujian pengaruh variabel sosialisai perpajakan terhadap kepatuhan pajak dilakukan analisis struktural. Analisis struktural hubungan antar variabel laten, yaitu memeriksa outer model atau meansurement model yaitu uji validitas dan reliabilitas konstruk. Berikut hasil Combined loadings and cross loadings.
Tabel 2 Combined loadings and cross-loadings

\begin{tabular}{|c|c|c|c|c|c|}
\hline & SP & Patuh & Type (a & SE & $\begin{array}{l}\mathrm{P} \\
\text { value }\end{array}$ \\
\hline SP1 & 0.825 & 0.062 & Reflect & 0.066 & $<0.001$ \\
\hline SP2 & 0.802 & -0.104 & Reflect & 0.066 & $<0.001$ \\
\hline SP3 & 0.785 & -0.104 & Reflect & 0.067 & $<0.001$ \\
\hline SP4 & 0.796 & 0.094 & Reflect & 0.066 & $<0.001$ \\
\hline SP5 & 0.844 & 0.046 & Reflect & 0.066 & $<0.001$ \\
\hline KP2 & 0.020 & 0.775 & Reflect & 0.067 & $<0.001$ \\
\hline KP4 & 0.010 & 0.802 & Reflect & 0.066 & $<0.001$ \\
\hline KP5 & -0.078 & 0.837 & Reflect & 0.066 & $<0.001$ \\
\hline KP6 & -0.091 & 0.793 & Reflect & 0.066 & $<0.001$ \\
\hline KP7 & 0.021 & 0.743 & Reflect & 0.067 & $<0.001$ \\
\hline KP8 & 0.015 & 0.855 & Reflect & 0.066 & $<0.001$ \\
\hline KP9 & 0.108 & 0.796 & Reflect & 0.066 & $<0$ \\
\hline
\end{tabular}

Dari tabel 2 sudah memenuhi kriteria validitas konvergen karena nilai loading faktor sudah di atas 0,70 atau untuk indicator dengan loading antara 0,40 dan 0,70 bisa dipertimbangkan dengan melihat keputusan menghapus terhadap nilai (AVE) average variance extracted dan composite reliability. Penelitian di atas juga sudah menunjukan nilai signifikan ( $p$-value $<0,05$ ).

\section{Laten Variable Correlations}

Tabel 3 Laten Variable Coefficient

\begin{tabular}{|l|l|l|}
\hline & SP & Patuh \\
\hline R-square & & 0.279 \\
\hline Adj. R-Squared & & 0.274 \\
\hline Composite Reliab & 0.905 & 0.926 \\
\hline Cronbach' alpha & 0.869 & 0.906 \\
\hline Avg. Var. Extrac & 0.657 & 0.642 \\
\hline Full collin. VIF & 1.253 & 1.253 \\
\hline Q- sguared & & 0.272 \\
\hline
\end{tabular}

Pada table 3 output menyajikan dua ukuran leabilitas instrument yaitu nilai composit reliability dan Cronbac's alpha, keduanya harus bernilai di atas 0,7 pada table di atas nilai composite reliability sebesar 0,905 dan 0,926 sedangkan nilai Cronbach alpha sebesar 0.869 dan 0.906 Selain itu harus juga melihat Q sguared lebih besar dari nol nilai Q sguare pada penelitian di atas sudah 0.272 . Setelah memeriksa validitas konvergen 
selanjutnya dilakukan pemeriksaan validitas diskriminan dengan melihat nilai laten variabel. Berikut tabel laten varibel correlations.

Tabel 4 Correlations among l.vs. with sq. rts. of AVEs

\begin{tabular}{|l|l|l|}
\hline & SP & Patuh \\
\hline SP & $(0.810)$ & 0.450 \\
\hline Patuh & 0.450 & $(0.801)$ \\
\hline
\end{tabular}

\begin{tabular}{|l|l|l|}
\hline \multicolumn{3}{|l|}{ P Value for Correlations } \\
\hline & SP & Patuh \\
\hline SP & 1.000 & $<0.001$ \\
\hline Patuh & $<0.001$ & 1.000 \\
\hline
\end{tabular}

Pada tabel 4 dapat disimpulkan bahwa validitas diskriminan telah terpenuhi yaitu akar AVE paada kolom diagonal lebih besar daripada korelasi antarkonstruk pada kolom yang sama. Pada able di atas nilai AVE untuk variable Sosialisasi perpajakan sebesar 0.810 lebih besar dari pada 0.450 . Nilai AVE untuk variable Patuh sebesar 0.801 lebih besar dari 0.450 .

Gambaran lebih jelas mengenai uji hipotesis pengaruh Sosialisasi perpajakan terhadap kepatuhan pajak dapat dilihat pada gambar di bawah ini.

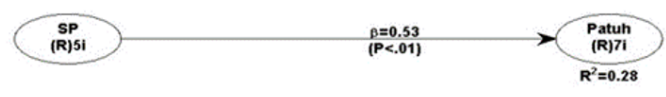

Gambar 1. Pengaruh sosiaslisasi perpajakan terhadap kepatuhan pajak

Hasil pengujian di atas dapat diperoleh pengaruh langsung sosialiasi perpajakan terhadap kepatuhan pajak adalah 0.53 dan signifikan dengan nilai $\mathrm{P}<0,01$. Nilai $\mathrm{R}^{2}$ sebesar 0.28 menunjukan variabel sosialisasi perpajakan mempengari $28 \%$ kepatuhan pajak sisanya dipengaruhi oleh variabel lain.

Gambar 1 menunjukan bahwa sosialiasi berpengaruh terhadap kepatuhan pajak ini bisa di lihat dari P Value lebih kecil dari 0,05 dengan $\mathrm{R}$ Square 0.28 atau sosialisasi perpajakan terhadap kepatuhan pajak berpengaruh sebesar $28 \%$ sisanya dipengaruhi oleh variabel lain.
Hasil tersebut sejalan dengan hipotesis awal sosialisasi perpajakan berpengaruh terhadap kepatuhan pajak oleh karena itu penelitian tersebut mendukung beberapa penelitian terdahulu. Sosialisasi perpajakan berpengaruh signifikan positif terhadap pengetahuan perpajakan dan kepatuhan perpajakan (Anwar, 2016). Penelitian tersebut didukung oleh penelitian Hasil penelitian Herlambang yang menunjukkan sosialisasi perpajakan secara dampak, telah mampu memberikan peningkatan bagi kepatuhan atas pajak sesuai dengan Peraturan Pemerintah Nomor 46 Tahun 2013 (Herlambang, 2018). Sejalan dengan hasil penelitian Sudrajat menunjukan bahwa pemanfaatan tekhnologi informasi, sosialisasi pajak dan pengetahuan pajak berpengaruh positif dan signifkan terhadapkepatuhan Wajib Pajak secara parsial. Sedangkan pengujian secara simultan berpengaruh terhadap kepatuhan pajak. Peningkatan sosialisasi yang dilakukan oleh aparat pajak akan meningkatkan kepatuhan pajak (Sudrajat, 2015). Semakin banyaknya sosialisasi orang yang mengetahui manfaat pajak akan lebih banyak, sehingga kepatuhan juga akan meningkat.

\section{Pengaruh Pengetahuan Perpajakan Terhadap Kepatuhan Pajak}

Tabel 5 Combined loadings and cross-loadings

\begin{tabular}{|c|c|c|c|c|c|}
\hline & Ratub & $\begin{array}{c}\text { Pense } \\
\text { tahpan }\end{array}$ & $\begin{array}{c}\text { Type (as } \\
\text { defined) }\end{array}$ & SE & $\begin{array}{c}\text { P } \\
\text { Value }\end{array}$ \\
\hline KP2 & $(0.775)$ & -0.145 & Reflective & 0.067 & $<0.001$ \\
\hline KP4 & $(0.802)$ & 0.138 & Reflective & 0.066 & $<0.001$ \\
\hline KP5 & $(0.837)$ & -0.061 & Reflective & 0.066 & $<0.001$ \\
\hline KP6 & $(0.793)$ & 0.201 & Reflective & 0.066 & $<0.001$ \\
\hline KP7 & $(0.743)$ & -0.076 & Reflective & 0.067 & $<0.001$ \\
\hline KP8 & $(0.855)$ & -0.081 & Reflective & 0.066 & $<0.001$ \\
\hline KP9 & $(0.796)$ & 0.024 & Reflective & 0.066 & $<0.001$ \\
\hline PP1 & 0.209 & $(0.640)$ & Reflective & 0.069 & $<0.001$ \\
\hline PP2 & 0.109 & $(0.624)$ & Reflective & 0.069 & $<0.001$ \\
\hline PP3 & 0.014 & $(0.776)$ & Reflective & 0.067 & $<0.001$ \\
\hline PP4 & -0.222 & $(0.805)$ & Reflective & 0.066 & $<0.001$ \\
\hline PP5 & -0.120 & $(0.702)$ & Reflective & 0.068 & $<0.001$ \\
\hline PP6 & 0.084 & $(0.601)$ & Reflective & 0.069 & $<0.001$ \\
\hline
\end{tabular}


Dari tabel 5 sudah memenuhi kriteria validitas konvergen karena nilai loading faktor sudah di atas 0,70 atau untuk indicator dengan loading antara 0,40 dan 0,70 bisa dipertimbangkan dengan melihat keputusan menghapus terhadap nilai (AVE) average variance extracted dan composite reliability. Penelitian di atas juga sudah menunjukan nilai signifikan ( $\mathrm{p}$-value $<0,05$ ).

Tabel 6 Laten Variable Coefficient

\begin{tabular}{|l|l|l|}
\hline & Kepatuhan & Pengetahuan \\
\hline R-Square & 0.268 & \\
\hline Adj. R.Squared & 0.263 & \\
\hline $\begin{array}{l}\text { Composite } \\
\text { Reliability }\end{array}$ & 0.926 & 0.847 \\
\hline Cronbach's alpha & 0.906 & 0.783 \\
\hline Avg. var. extrac & 0.642 & 0.484 \\
\hline Full collin VIF & 1.294 & 1.294 \\
\hline Q.Squared & 0.269 & \\
\hline
\end{tabular}

Pada tabel 6 output menyajikan dua ukuran leabilitas instrument yaitu nilai composit reliability dan Cronbac's alpha, keduanya harus bernilai di atas 0,7 pada table di atas nilai composite reliability sebesar 0,926 dan 0,847 sedangkan nilai Cronbach alpha sebesar 0.906 dan 0.783 Selain itu harus juga melihat Q sguared lebih besar dari nol nilai Q sguare pada penelitian di atas sudah 0.269 .

Tabel 7 Correlation among l.vs. with sq.rts.of AVES

\begin{tabular}{|l|l|l|}
\hline & Patuh & Pengetahuan \\
\hline Patuh & $(0.801)$ & 0.477 \\
\hline Pengetahuan & 0.477 & $(0.696)$ \\
\hline
\end{tabular}

\begin{tabular}{|l|l|l|}
\hline \multicolumn{3}{|l|}{ P Value for Correlations } \\
\hline & Patuh & Pengetahuan \\
\hline Patuh & 1.000 & $<0.001$ \\
\hline Pengetahuan & $<0.001$ & 1.000 \\
\hline
\end{tabular}

Dari tabel 7 dapat disimpulkan bahwa validitas diskriminan telah terpenuhi yaitu akar AVE paada kolom diagonal lebih besar daripada korelasi antarkonstruk pada kolom yang sama. Pada table di atas nilai AVE untuk variable Kepatuhan perpajakan sebesar 0.801 lebih besar dari pada 0.477. Nilai AVE untuk variable Pengetahuan perpajakan sebesar 0.696 lebih besar dari 0.477 .

Gambaran lebih jelas mengenai uji hipotesis pengaruh Sosialisasi perpajakan terhadap kepatuhan pajak dapat dilihat pada gambar di bawah ini.

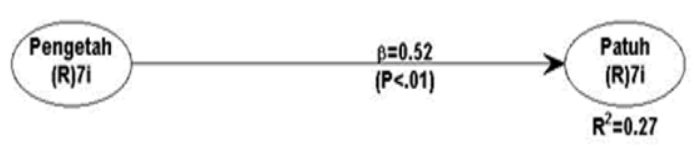
Gambar 2. Pengaruh sosiaslisasi perpajakan
terhadap kepatuhan pajak

Hasil pengujian di atas dapat diperoleh pengaruh langsung Pengetahuan perpajakan terhadap kepatuhan pajak adalah 0.52 dan signifikan dengan nilai $\mathrm{P}<0,01$. Nilai $\mathrm{R}^{2}$ sebesar 0.27 menunjukan bahwa $27 \%$ kepatuhan pajak dipengaruhi oleh varibel pengetahuan pajak sisanya dipengaruhi oleh variabel lain. Penelitian ini mendukung penelitian sebelumnya, Penelitian yang dilakukan oleh beberapa peneliti terdahulu yang menguji pengaruh pengetahuan terhadap kepatuhan pajak membuktikan bahwa pengetahuan berpengaruh signifikan positif terhadap kepatuhan pajak. Anwar (2016) membuktikan bahwa sosialisasi perpajakan berpengaruh signifikan positif terhadap pengetahuan perpajakan dan kepatuhan perpajakan. Sudrajat (2015) menunjukan bahwa pemanfaatan tekhnologi informasi, sosialisasi pajak dan pengetahuan pajak berpengaruh positif dan signifkan terhadap kepatuhan. 
Tabel 8 Combined loadings and cross-loadings

\begin{tabular}{|c|c|c|c|c|c|c|}
\hline & Kerpabsban & Densetzahwan & Sogialisasi & $\begin{array}{l}\text { Type (as } \\
\text { defined) }\end{array}$ & $S E$ & $\begin{array}{c}P \\
\text { Value }\end{array}$ \\
\hline $\mathrm{KP2} 2$ & $(0.775)$ & -0.154 & 0.053 & Reflective & 0.067 & $<0.001$ \\
\hline KP4 & $(0.802)$ & 0.141 & -0.023 & Reflective & 0.066 & $<0.001$ \\
\hline KP5 & $(0.837)$ & -0.052 & -0.065 & Reflective & 0.066 & $<0.001$ \\
\hline KP6 & $(0.799)$ & 0.232 & $-0.13 s$ & Reflective & 0.066 & $<0.001$ \\
\hline KP7 & $(0.743)$ & -0.084 & 0.093 & Reflective & 0.067 & $<0.001$ \\
\hline KPS & $(0.855)$ & -0.084 & 0.050 & Reflective & 0.066 & $<0.001$ \\
\hline KP9 & $(0.796)$ & 0.000 & 0.112 & Reflective & 0.066 & $<0.001$ \\
\hline $\mathrm{PP} 1$ & 0.130 & $(0.640)$ & 0.192 & Reflective & 0.069 & $<0.001$ \\
\hline $\mathrm{pP} 2$ & 0.054 & $(0.624)$ & 0.137 & Reflective & 0.069 & $<0.001$ \\
\hline Pp3 & 0.012 & $(0.776)$ & -0.002 & Reflective & 0.067 & $<0.001$ \\
\hline Pp4 & -0.159 & $(0.805)$ & -0.170 & Reflective & 0.066 & $<0.001$ \\
\hline Pp5 & -0.114 & $(0.702)$ & 0.000 & Reflective & 0.065 & $<0.001$ \\
\hline PP6 & 0.135 & $(0.601)$ & -0.116 & Reflective & 0.069 & $<0.001$ \\
\hline $\mathrm{SP} 1$ & 0.086 & -0.060 & $(0.825)$ & Reflective & 0.066 & $<0.001$ \\
\hline$S P 2$ & -0.061 & -0.102 & $(0.802)$ & Reflective & 0.066 & $<0.001$ \\
\hline SP3 & -0.170 & 0.155 & $(0.785)$ & Reflective & 0.067 & $<0.001$ \\
\hline Sp4 & 0.065 & 0.063 & $(0.796)$ & Reflective & 0.066 & $<0.001$ \\
\hline SP5 & 0.065 & -0.051 & $(0.844)$ & Reflective & 0.066 & $<0.001$ \\
\hline
\end{tabular}

Dari tabel 8 sudah memenuhi kriteria validitas konvergen karena nilai loading faktor sudah di atas 0,70 atau untuk indicator dengan loading antara 0,40 dan 0,70 bisa dipertimbangkan dengan melihat keputusan menghapus terhadap nilai (AVE) average variance extracted dan composite reliability. Penelitian di atas juga sudah menunjukan nilai signifikan ( $\mathrm{p}$-value $<0,05$ ).

Tabel 9 Laten Variable Coefficient

\begin{tabular}{|l|c|c|c|}
\hline & Kepatuhan & Rengetahuan & Sosialisass \\
\hline R-Square & 0.385 & 0.188 & \\
\hline Adj. Rusquared & 0.377 & 0.183 & \\
\hline $\begin{array}{l}\text { Composite Relia- } \\
\text { bility }\end{array}$ & 0.926 & 0.847 & 0.905 \\
\hline Cronbach's alpha & 0.906 & 0.783 & 0.869 \\
\hline Avg. var. extrac & 0.642 & 0.484 & 0.657 \\
\hline Full sollin VIF & 1.455 & 1.351 & 1.308 \\
\hline QSsquared & 0.385 & 0.189 & \\
\hline
\end{tabular}

Pada tabel 9 output menyajikan dua ukuran leabilitas instrument yaitu nilai composit reliability dan Cronbac's alpha, keduanya harus bernilai di atas 0,7 pada table di atas nilia composite reliability sebesar $0,926,0,847$ dan 0,905 sedangkan nilai Cronbach alpha sebesar $0.906,0.783$ dan
0.869 Selain itu harus juga melihat Q sguared lebih besar dari nol nilai Q sguare pada penelitian di atas sudah 0.385 dan 0,189 .

Tabel 10 Correlation among l.vs. with sq.rts.of AVEs

\begin{tabular}{|l|c|c|c|}
\hline & Kepatuhan & Pengetahuan & Sosialisasi \\
\hline Kepatuhan & $(0.801)$ & 0.477 & 0.450 \\
\hline Pengetahuaan & 0.477 & $(0.696)$ & 0.375 \\
\hline Sosialisasi & 0.450 & 0.375 & $(0.810)$ \\
\hline
\end{tabular}

\begin{tabular}{|l|c|c|c|}
\multicolumn{4}{|c|}{ PValue for Correlations } \\
\hline & Kepatuhan & Pengetahuan & Sosialisasi \\
\hline Kepatuhan & 1.000 & $<0.001$ & $<0.001$ \\
\hline Pengetahuman & $<0.001$ & 1.000 & $<0.001$ \\
\hline Sosialisasi & $<0.001$ & $<0.001$ & 1.000 \\
\hline
\end{tabular}

Dari tabel 10 dapat disimpulkan bahwa validitas diskriminan telah terpenuhi yaitu akar AVE paada kolom diagonal lebih besar daripada korelasi antarkonstruk pada kolom yang sama. Pada table di atas nilai AVE untuk variable Kepatuhan perpajakan sebesar 0.801 lebih besar dari pada 0.450 dan 0,477 . Nilai AVE untuk variable pengetahuan sebesar 0.696 lebih besar dari 0.477 dan 0.375 . Sedangkan nilai AVE sosialisasi perpajakan sebesar 0.810 lebih besar dari 0.450 dan 0.375 .

Pengaruh sosialisasi perpajakan terhadap kepatuhan pajak melalui pengetahuan pajak

Gambar 3 menunjukan hasil pengujian hipotesis 3 atau pengujian variabel intervening. Sebelum melihat hasil pengujian intervening untuk hipotesis langsung sosialiasi perpajakan terhadap kepatuhan pajak sebesar 0.53 dan signifikan dengan nilai $\mathrm{P}<0,01$. Hasil pengujian intervening atau indirect effect turun menjadi 0,38 namun tetap signifikan. Hal ini menunjukan pengetahuan perpajakan memediasi secara parsiel pegaruh sosialisi perpajakan terhadap kepatuhan pajak. Bentuk parsiel mediasi menunjukan bahwa pengetahuan bukan satu-satunya pemediasi hubungan sosialisasi terhadap kepatuhan pajak namun terdapat pemediasi lain. 


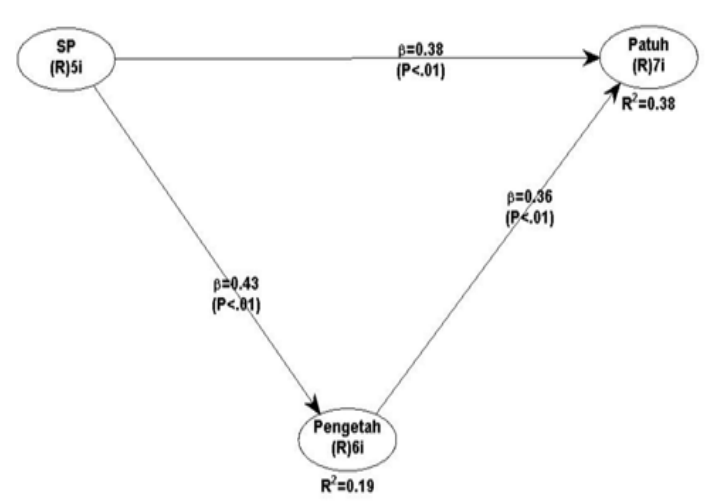

\section{Gambar 3. Pengaruh Sosialisasi Perpajakan terhadap Kepatuhan Pajak melalui Pengetahuan Pajak}

Hasil Pengujian tersebut mendukung hipotesis awal, penelitian oleh Sudrajat menunjukan bahwa pemanfaatan tekhnologi informasi, sosialisasi pajak dan pengetahuan pajak berpengaruh positif dan signifkan terhadapkepatuhan Wajib Pajak (Sudrajat, 2015). Untuk hasil penelitian Anwar juga membuktikan bahwa pengetahuan pajak mampu memediasi hubungan sosialisasi perpajakan kepatuhan perpajakan (Anwar, 2016).

\section{KESIMPULAN}

Sosialiasi perpajakan berpengaruh terhadap kepatuhan pajak sebesar 0.53 dan signifikan dengan nilai $P<0,01$. Nilai $R^{2}$ sebesar 0.28 menunjukan variabel sosialisasi perpajakan mempengaruhi $28 \%$ kepatuhan pajak sisanya dipengaruhi oleh variabel lain.

Pengetahuan perpajakan berpengaruh secara langsung terhadap kepatuhan pajak sebesar 0.52 dan signifikan dengan nilai $\mathrm{P}<0,01$. Nilai $\mathrm{R}^{2}$ sebesar 0.27 menunjukan bahwa 27\% kepatuhan pajak dipengaruhi oleh varibel pengetahuan pajak sisanya dipengaruhi oleh variabel lain.

Sosialisasi berpengaruh secara langsung terhadap kepatuhan pajak sebesar 0,53, hasil pengujian intervening atau indirect effect turun menjadi 0,38 namun tetap signifikan. Hal ini menunjukan pengetahuan perpajakan memediasi secara parsiel pegaruh sosialisi perpajakan terhadap kepatuhan pajak. Bentuk parsiel mediasi menunjukan bahwa pengetahuan bukan satu-satunya pemediasi hubungan sosialisasi terhadap kepatuhan pajak namun terdapat pemediasi lain.

\section{Daftar Pustaka}

Alm, J. (1991). A Perspective on The Experimental Analysis of Taxpayer Reporting. The Accounting Review, 66(3), 577-593.

Andreas \& Savitri, E. (2015). The Effect of Tax Socialization, Tax Knowledge, Expediency of Tax ID Number and Service Quality on Taxpayers Compliance With Taxpayers Awareness as Mediating Variables. 2nd Global Conference on Business and Social Science. Bali, Indonesia.

Anwar, R. A. (2016). Pengaruh Sosialisasi Perpajakan Terhadap Kepatuhan Perpajakan Wajib Pajak Usaha Mikro Kecil Dan Menengah (UMKM) Di Surakarta Dengan Pengetahuan Perpajakan Sebagai Variabel Pemediasi. Jurnal InFestasi, 12 No 1, 66-74.

Faturahman, B. (2018). Pengaruh Pengetahuan Perpajakan Dan Tax Amnesty Terhadap Kepatuhan Perpajakan Wajib Pajak Orang Pribadi Pasca tax Amnesty. Seminar Nasional dan Call for Paper:Manajemen, Akuntansi dan Perbankan. Universitas ISlam Batik. Surakarta. Jawa Tengah.

Herlambang, A. A. (2018). Dampak Sosialisasi Perpajakan Bagi Pemilik Usaha Pada Sektor. ULTIMA Accounting ISSN 2085-4595, 77-95.

Mardiasmo. (2018), Tax, Revisi 2018, Yogyakarta : Penerbit Andi

Perbendaharaan, D. K. (2018). Kajian Fiskal Regional Triwulan I Provinsi Kepulauan Riau. Kepulauan Riau.

Pratomo, D. P. (2018). Pengaruh Sosialisasi Perpajakan Dan Help Desk Terhadap Kepatuhan Wajib Pajak (Studi Pada Kantor Pelayanan Pajak Pratama Cianjur).

Resmi, S. (2017). Perpajakan Teori dan Kasus Edisi 10-Buku 1. Jakarta: Salemba Empat.

Sudrajat, A. O. (2015). Pemanfaatan Teknologi Informasi, Sosialisasi Pajak, Pengetahuan Perpajakan, dan Kepatuhan Pajak. Jurnal Riset Akuntansi dan Perpajakan JRAP Universitas Pancasila, 2 No 2. 